\title{
Energy Pattern and Conservations of Condiment Produced from Soybean (Glycine max)
}

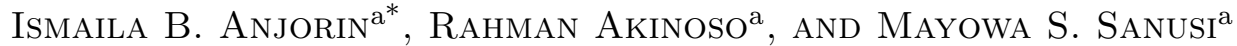 \\ ${ }^{a}$ Department of Food Technology, Faculty of Technology, University of Ibadan, Ibadan, Nigeria \\ ${ }^{*}$ Corresponding author \\ anjorin.ismaila@gmail.com \\ TEL: +2348036965693
}

Received: 17 August 2017; Published online: 18 April 2018

\begin{abstract}
Energy being one of the largest operating expenses in most organizations especially manufacturing and processing industries leading to considerable scope for energy conservation and hence cost. Information on energy utilization and conservation pattern were obtained based on time taken, number of person involved and sources of energy using standard energy equations. A total of $445.40 \pm$ $17.32 \mathrm{MJkg}^{-1}$ where thermal energy $(420 \mathrm{MJ} \approx 94 \%)$ and manual energy $(25.40 \mathrm{MJ} \approx 6 \%$ ) were the only forms of energy used during production process. Conservation approach I resulted in mean energy of $72.08 \pm 1.73 \mathrm{MJkg}^{-1}$ where electrical energy, manual energy and thermal energy accounted for $1.75 \mathrm{MJ}$ (3\%) 7.34MJ (10\%) and 62.99MJ (87\%) respectively. Conservation approach II reduced the energy further to $57.24 \pm 1.73 \mathrm{MJkg}^{-1}$ as the operation was thermal energy dependent, followed by manual and electrical energy with energy values of $48.13,7.33$ and $1.78 \mathrm{MJ}$ equivalent to $84.10 \%, 12.80 \%$ and $3.10 \%$ accordingly. Conclusively, traditional method of processing utilized highest energy (445.40MJ) followed by conservation approach I $(72.08 \mathrm{MJ})$ and conservation approach II $(57.24 \mathrm{MJ})$ was least in energy demand. Conservation approach II permits energy conservation to be $87 \%$ as compared with traditional method.
\end{abstract}

Keywords: Condiment; Conservation approach; Energy; Traditional process; Soybean

\section{Introduction}

Soybean (Glycine max) is one of the most important legumes in the world which provides vegetable protein for millions of human. It is most nutritious and easily digested food of the bean family. The soybean is considered as one of the richest and cheapest sources of protein. It is a staple in the diet of humans and animals in different corners of world today. Soybean contains $35-40 \%$ protein on a dry-weight basis (Liu, 1997); these proteins contain all amino acids essential to human nutrition but it is deficient in sulphur containing amino acids, however, soy products almost equivalent to animal sources in protein quality but with less saturated fat and no cholesterol. Its consumption has been discouraged due to its beany taste, off flavor and anti-nutritional factor such as phytate, saponin (Akande, Doma, Agu, \& Adam, 2010) and lectins (Lajolo \& Genovese, 2002). In spite of this occurrence, soybean has been receiving attention in Nigeria as diet. A popular product that is common in the soybean producing areas of the country is soybean daddawa (also referred to as soydaddawa or iru) which is a food flavoring condiment produced from whole soybean by means of fermentation and the end product is similar in its characteristic stickiness and pungent ammonical smell to that of iru made from fermented locust 
bean (Parkia biglobosa) seeds.

The production of condiment from soybean has been reported by Oboh (2006). The processing of soybean into condiments require energy of different forms. Energy development, management and improvement must have predetermined plans and strategies and this can be achieved through a proper understanding of its utilization and consumption pattern where it is applicable (Aderemi, Ilori, Aderemi, \& Akinbami, 2009). This makes energy one of the largest controllable costs in most organizations especially manufacturing and processing industries leading to considerable scope for energy conservation and hence cost (Jekayinfa \& Bamgboye, 2006).

Energy conservation contributes to profitability of the industry, reduction in environmental impact, and conservation of depleting non renewable energy sources such as crude oil, natural gas and coal. It is now widely accepted fact, that current production of non-renewable energy cannot satisfy the ever increasing population and industrial needs which demands for conservations of energy by processes and at same time development of renewable energy. Energy audit is the review of the total energy used and costs, normally performed in conjunction with site investigation. It involves the classification of the energy sources and their contribution in running the factory (Jekayinfa \& Bamgboye, 2006). It provides a structural review of how energy is being purchased, managed and used with the aim of identifying opportunities for energy cost saving through improved services [6]. It also gives the estimate of potential annual energy savings with implementation costs and pay back periods. Effective energy utilization in the manufacturing sector required the in-depth knowledge of energy performance of machines, and operations related to the production process as these vary from industry to industry. To reduce operating cost to a minimum, the cost of energy consumption which is prime factor under operating cost must be well monitored (Wang, 2009). Some reports on energy audit and survey have been published on processing of palm oil (Akinoso \& Omolola, 2011), sugar beet production (Mrini, Senhaji, \& Pimentel, 2002), cashew nut processing (Jekayinfa \& Bamgboye, 2006) and palm kernel processing (Jekayinfa \& Bamgboye, 2007), cowpea flour production (Akinoso, Olapade, \& Akande, 2013) and condiment from locust beans (Akinoso \& Adedayo, 2012), bambara nut (Anjorin, Sanusi, \& Hussein, 2015) and ogiri (Anjorin et al., 2015) among others. However, energy quantification and data were not evident on condiments produced from soybean despite several researches on the legume. Therefore, the objective of this paper is to provide data on energy pattern and subsequent conservations for the processing operation of soybean condiment (iru).

\section{Materials and Methods}

Data on energy utilization and conservation were obtained on basic unit operations, quantity of fuel used, time taken, gender involved and sources of energy used (Table 1). Each process was repeated three times and obtained data were subjected to descriptive analysis using SPSS software at $5 \%$ significance level. Mean was reported for each unit operations.

\subsection{Traditional Process}

Method described by Oboh (2006) was adopted for traditional condiment production from soybean. One kilogram $(1 \mathrm{~kg})$ of soybean was weighed, sorted, winnowed (as preliminary operation), washed and boiled at $\left(100{ }^{\circ} \mathrm{C}\right.$ to 105 ${ }^{\circ} \mathrm{C}, 760 \mathrm{mmHg}$ ) in a cast iron pot for $12 \mathrm{~h}$ using air dried wood as source of fuel. The boiled water was used to soak the seeds overnight prior to dehulling by rubbing the cotyledons between palms of the hands and subsequent washing with potable water to remove the hulls. The cleaned cotyledons were boiled in a cast iron pot for another $2 \mathrm{~h}$ using air dried wood, boiling water was drained using plastic sieve. Drained cotyledons were spread and wrapped on already cleaned banana leaves, then wrapped in a polythene bag before being placed in an air tight container for spontaneous fermentation for 4 days at ambient temperature. 
Energy usage during production of soybean condiment $\mid 113$

Table 1: Data used in evaluating energy consumption pattern during production process and conservation approach I and II of soybean into condiment

\begin{tabular}{|c|c|c|c|}
\hline Unit Operation & Required Parameters & $\begin{array}{l}\text { Production } \\
\text { Process }\end{array}$ & $\begin{array}{l}\text { Conservation } \\
\text { Approaches }\end{array}$ \\
\hline \multirow[t]{2}{*}{ Preliminary Operations } & Number of persons involved & 1 & 1 \\
\hline & Time taken $(\mathrm{h})$ & $0.23 \mathrm{~h}$ & $0.23 \mathrm{~h}$ \\
\hline \multirow{3}{*}{ First Boiling } & Air dried wood consumed l & $24 \mathrm{~kg}$ & NA \\
\hline & Number of Persons involved in boiling & 2 & NA \\
\hline & Time taken for boiling $(\mathrm{h})$ & $12 \mathrm{~h}$ & NA \\
\hline \multirow{2}{*}{ Soaking } & Number of persons involved & 1 & 1 \\
\hline & Time taken $(\mathrm{h})$ & $0.1 \mathrm{~h}$ & $0.10 \mathrm{~h}$ \\
\hline \multirow[t]{2}{*}{ Dehulling and Washing } & Number of persons involved & 2 & NA \\
\hline & Time taken $(\mathrm{h})$ & $1.78 \mathrm{~h}$ & NA \\
\hline \multirow[t]{2}{*}{ Mechanized Dehulling } & Number of persons involved & NA & 2 \\
\hline & Time taken (h) & NA & $0.33 \mathrm{~h}$ \\
\hline \multirow{2}{*}{ Washing } & Number of persons involved & NA & 2 \\
\hline & Time taken (h) & NA & $0.50 \mathrm{~h}$ \\
\hline \multirow[t]{5}{*}{ Second Boiling } & Air dried wood consumed l & $4 \mathrm{~kg}$ & NA \\
\hline & Number of Persons involved in boiling & 2 & 1 \\
\hline & Fuel consumed l (Kerosene) & NA & $0.70 \mathrm{~L}$ \\
\hline & Fuel consumed (LPG) & NA & $0.31 \mathrm{~kg}$ \\
\hline & Time taken for boiling (h) & $2 \mathrm{~h}$ & $3.5 \mathrm{~h}$ \\
\hline \multirow{2}{*}{ Wrapping } & Number of persons involved & 2 & 2 \\
\hline & Time taken (h) & $0.68 \mathrm{~h}$ & $0.68 \mathrm{~h}$ \\
\hline \multirow[t]{2}{*}{ Fermentation } & Number of persons involved & 1 & 1 \\
\hline & Time taken (h) & $0.12 \mathrm{~h}$ & $0.12 \mathrm{~h}$ \\
\hline \multirow[t]{3}{*}{ Drying } & Number of persons involved & NA & 2 \\
\hline & Time taken (h) & NA & $1 \mathrm{~h}$ \\
\hline & Weight of charcoal (kg) & NA & $1.2 \mathrm{~kg}$ \\
\hline \multirow[t]{2}{*}{ Milling } & Number of persons involved & NA & 2 \\
\hline & Time taken (h) & NA & $0.16 \mathrm{~h}$ \\
\hline \multirow[t]{2}{*}{ Packaging } & Number of persons involved & 2 & 2 \\
\hline & Time taken (h) & $0.25 \mathrm{~h}$ & 0.25 \\
\hline
\end{tabular}

NA: Not Applicable 


\subsection{Conservation Approaches for Processing Soybean into Condiment}

Soybean of $1 \mathrm{~kg}$ was weighed, sorted, winnowed, washed and soaked for 24h. The soaked seeds were dehulled in a locally fabricated dehuller and subsequent washing with waters to remove the hulls. The cotyledons were boiled for $3.5 \mathrm{~h}$ in an aluminum pot using kerosene in a kerosene stove as source of fuel, boiling water was drained using plastic sieve. Drained cotyledons were spread and wrapped in already sterilized banana leaves, placed in polythene bag and put in an air tight container for inherent fermentation for the period of 4 days at ambient temperature. The fermented soybean condiments were dried using coal powered drier and milled in an attrition mill prior to packaging using high density polyethylene. These procedures were repeated during conservation approach II with exception of Liquefied Propane Gas (LPG) being used as source of fuel during boiling operation.

\subsection{Energy Quantification}

Energy utilization during each operation was categorized as electrical, thermal, and manual energy as represented in equation (1) (2) and (3). These modes of energy were estimated using approach adopted by Akinoso and Adedayo (2012) during energy utilization pattern of processing African Locust beans (Parkia biglobosa) into condiment.

\section{Manual Energy}

Manual energy was estimated based on the values recommended by Goyal, Jogdand, and Agrawal (2014) as stated in equation (1):

$$
E_{M}=0.75 \times N \times T_{a}(k W)
$$

Where $0.75=$ the average power of a normal human labour in $\mathrm{kW}, N=$ number of person involved in the operation; and $T a=$ useful time spent to accomplish a given task in hours.

\section{Thermal Energy}

The thermal energy was estimated according to the heating source term used by (Rajput, 2001) which establishes that the thermal energy $E$ is directly proportional to amount of fuel used $W(M J)$ as expressed in equation (2):

$$
E=C f W(M J)
$$

Where $C f$, is the constant of proportionality which represents the calorific value (heating value) of fuel used, $\mathrm{W}$ is the quantity of fuel consumed and $\mathrm{E}$ is the quantity of energy consumed. Calorific value of typical air dried wood (15MJ/kg), (Kerosene (43.7 MJ/L), Liquefied Propane Gas (LPG) (50.35MJ/kg) and charcoal (27MJ/kg) (Akinoso \& Adedayo, 2012).

\section{Electrical Energy}

Equipment using electrical energy, the rated horse power of each motor was multiplied by the corresponding hours of operation as represented in equation (3). A motor efficiency of $80 \%$ was assumed to compute the electrical input (Rajput, 2001).

$$
E_{p}=\Delta P N
$$

Where Ep is the electrical energy consumed in $\mathrm{kWh}=\mathrm{kJ}, \mathrm{P}$ is the rated power of motor in $\mathrm{kW}$ (dehuller, 4.48; Attrition Mill, 2.98 and Impulse sealer, 0.26), (Akinoso \& Adedayo, 2012). $\mathrm{N}$ is the time spent in hours (h) during the operation, $\Delta$ is the power factor (assumed to be 0.8 ).

\subsection{Total Energy Estimation (En)}

This was calculated by summation of all energy of each unit operation involved during the production of each condiment for traditional process and conservation approaches as stated in equation (4) and (5):

\section{Traditional Process}

$\left(E_{n}\right)=E_{P O}+E_{W A}+E_{F B}+E_{D}+E_{S B}+E_{W}+E_{F}+E_{P}$

Where $\mathrm{E}_{P O}, \mathrm{E}_{W A}, \mathrm{E}_{F B}, \mathrm{E}_{D}, \mathrm{E}_{W A}, \mathrm{E}_{S B}, \mathrm{E}_{D}$, $\mathrm{E}_{F}, \mathrm{E}_{D}, \mathrm{E}_{M}$, and $\mathrm{E}_{P}$ are energy for preliminary 
operation, washing, first boiling, dehulling, second boiling, wrapping, fermentation and packaging.

\section{Conservation Approaches}

$$
\begin{aligned}
E_{n}= & E_{P O}+E_{s}+E_{D}+E_{W A}+ \\
& E_{B}+E_{W}+E_{F}+E_{D}+E_{M}+E_{P}
\end{aligned}
$$

Where $\mathrm{E}_{P O}, \mathrm{E}_{s}, \mathrm{E}_{D}, \mathrm{E}_{W A}, \mathrm{E}_{B}, \mathrm{E}_{W}, \mathrm{E}_{F}, \mathrm{E}_{D}$, $\mathrm{E}_{M}$, and $\mathrm{E}_{P}$ are energy for preliminary operation, soaking, dehulling, washing, boiling, wrapping, fermentation, drying, milling and packaging respectively.

\section{Conservation Approaches}

Statistical analysis of all data was done with the Statistical Package for the Social Sciences (SPSS) (IBM Corp. Released 2013. IBM SPSS Statistics for Windows, Version 22.0. Armonk, NY: IBM Corp.). The mean values were considered at 95\% significance level using One-way Analysis of variance (ANOVA) procedure while Duncan multiple test was used to separate the means.

\section{Results and Discussion}

\subsection{Energy Requirement during Traditional Process of Soybean Condiment}

A total of $445.40 \pm 17.32 \mathrm{MJ} / \mathrm{kg}$ of energy was expended during the traditional process (Table 2). The energy intensity of this process was higher than the energy $(59.82 \pm 1.40 \mathrm{MJ} / \mathrm{kg})$ utilized during processing of condiment from locust beans (Parkia biglobosa) (Akinoso \& Adedayo, 2012); $2.38 \mathrm{MJ} / \mathrm{kg}$ used for extraction of crude soybean oil (Wang, 2009); 7.20 MJ/kg for palm oil production using electrical energy (Mahlia, Abdulmuin, Alamsyah, \& Mukhlishien, 2001) and 4.86 $\mathrm{MJ} / \mathrm{kg}$ utilized during production of burukutu (Ibrahim, Alex, \& Ierve, 2013). The differences in energy consumption can be adduced to crop physiology such as seed coat hardness, quantity of sample used, technology utilized and sources of energy.

During the operations, two major forms of energy were utilized which were thermal and manual energy, thermal energy (such as boiling operations) was estimated to be $420 \mathrm{MJ} / \mathrm{kg}$ while manual energy (such as preliminary operations (weighing, winnowing and sorting), soaking, dehulling, wrapping fermentation and packaging) accounted for $25.40 \mathrm{MJ} / \mathrm{kg}$, these operations amounting to $94 \%$ and $6 \%$ respectively.

\subsection{Energy Used by the Conservation Approaches}

In conservation approach I where kerosene was used during boiling operation a total of $72.08 \pm 1.73 \mathrm{MJ} / \mathrm{kg}$ of energy was used as against $445.40 \pm 17.32 \mathrm{MJ} / \mathrm{kg}$ consumed during the traditional process counterpart (Table 2). The drastic reduction in energy utilization can be linked to elimination of most energy demanding operation which was first boiling being replaced with $24 \mathrm{hrs}$ soaking, change in fuel source from firewood to kerosene with calorific value $43.7 \mathrm{MJ} / \mathrm{L}$ which tend to release high proportion of energy as a function of technological advancement of appliance used as well as change in cooking pot from mild steel to aluminium and manual dehulling being substituted with mechanical dehulling.

The energy intensity of this operation was higher as compared with semi-mechanized processing of condiment produced from locust bean where $67.56 \pm 1.30 \mathrm{MJ} / \mathrm{kg}$ was used [14] and energy conservation of condiments produced from bambara nut 25.64MJ was utilized [20]. However, the second boiling consumed $33.22 \pm 1.73 \mathrm{MJ}$ of total energy while $0.08 \pm 0.01 \mathrm{MJ}$ was utilized during soaking operation making the operation the most and least intensive energy consuming operations respectively. These two operations answered for $46.08 \%$ and $0.10 \%$ of the total energy input. Also, more than $75 \%$, of the energy was utilized by the two thermal operations (second boiling and drying), preliminary operations (weighing, winnowing and sorting), soaking, washing, wrapping and fermentation calculated to be $2.92 \%$, while mechanized dehulling, milling and packaging answered for $3.97 \%$. In this technique, electrical energy, manual energy and thermal energy accounted for $1.75 \mathrm{MJ}, 7.34 \mathrm{MJ}$ and $62.99 \mathrm{MJ}$ com- 
prising $3 \%, 10 \%$ and $87 \%$ respectively.

During conservation approach II where liquefied propane gas was used during boiling operation, In this process, preliminary operations, soaking and washing, accounted for $0.99 \mathrm{MJ}$ corresponding to $1.74 \%$, wrapping, mechanized dehulling, fermentation, milling and packaging utilized a total of $3.98 \mathrm{MJ}$ amounting to $6.95 \%$, while boiling and drying consumed $52.26 \mathrm{MJ}$ corresponding to $91.31 \%$. The total estimated energy of the process accounted for $57.24 \pm 1.73 \mathrm{MJ} / \mathrm{kg}$ as against $72.08 \pm 1.73 \mathrm{MJ} / \mathrm{kg}$ and $445.40 \pm 17.32 \mathrm{MJ} / \mathrm{kg}$ utilized during conservation approach I and traditional techniques. The total energy utilized during conservation approach II was less when compared to energy used during improved processing (semi-mechanized) of locust beans where $67.56 \pm 1.3 \mathrm{MJ} / \mathrm{kg}$ was consumed [14]

The further reduction in energy consumption as compared with conservation approach I can be attributed to change in fuel source from kerosene to LPG while other materials and operations remain the same. Reduction of energy as evidenced in conservation approach II justified the use of liquefied propane gas for the heating process with calorific value $50.35 \mathrm{MJ} / \mathrm{kg}$ making high proportion of its energy content to be converted to heat. However, boiling operation accounted for $18.36 \mathrm{MJ}$ of the total energy input while $0.08 \mathrm{MJ}$ was consumed during soaking making the operations most and least energy demanding operations corresponding to $32.08 \%$ and $0.14 \%$ respectively. Thermal operations (second boiling and drying) consumed a total of $52.26 \mathrm{MJ}$ which is more than three-quarter of the total energy input corresponding to 91.37 in percentage. Besides, mechanized dehulling, milling and packaging which represented $5.06 \%$ of the remaining energy input preliminary operations (weighing, winnowing and sorting), soaking, washing, wrapping and fermentation accounted for the smallest proportion of the energy input totaling $3.63 \%$. It was observed that, the operation was thermal energy dependent, followed by manual and electrical energy with energy values of $48.13,7.33$ and $1.78 \mathrm{MJ}$ equivalent to $84.10 \%, 12.80 \%$ and $3.10 \%$ accordingly.

\subsection{Comparison of Total Energy Usage during Processing Soybean into Condiment}

In the three operations, energy utilized during preliminary operation ranged between $0.17 \pm 0.06$ in conservation approach II to $0.17 \pm 0.01$ in traditional process amounting to $0.29 \%$ and $0.04 \%$ respectively. There were no significant differences in energy utilized during preliminary operations of the processes $(\mathrm{p}>0.05)$. First boiling operation accounted for a total of $378 \mathrm{MJ}$ in traditional process representing $84.87 \%$ of the energy usage during the operation. The operation was identified as most energy demanding operation and thus not applicable during conservation approach I and II. However, second boiling was involved during the three operations with energy values 63.00MJ, 33.22MJ, and $18.36 \mathrm{MJ}$ in traditional process, conservation approach I and II corresponding to $14.15 \%$, $46.08 \%$, and $32.08 \%$. Significant differences were evidenced at $(\mathrm{P}=0.05)$ during the operation.

The energy utilized during traditional process can be traced to low efficiency of energy (about $10 \%$ ) from firewood as well as the calorific value $(15 \mathrm{MJ} / \mathrm{kg})$ which makes firewood to utilize more quantity of firewood to attain heating process [19]. Also, manual dehulling (Hand dehulling) in traditional process was higher than conservation approaches where in both approaches locally fabricated mechanized dehuller was adopted for the operation. The energy values were $2.67 \pm 0.54$ in traditional process, $1.68 \pm 0.52 \mathrm{MJ}$ in conservation approach I and $1.68 \pm 0.52$ in conservation approach II corresponding to $0.60 \%, 2.33 \%$ and $2.93 \%$ of respective energy input during the operation. This could be attributed to the reduction in the dehulling time because mechanical dehuller was used for both conservation approaches which saves time as compare with traditional process that used manual method and this agreed with the findings of [7] that the duration of processing is a major parameter in estimating energy utilization.

There were significant differences between traditional process and conservation approaches but significant differences were not established between conservation approaches I and II. 
Table 2: Energy utilization during production process and conservation approach I and II of producing soybean condiment

\begin{tabular}{lllllll}
\hline Unit Operation & \multicolumn{2}{l}{$\begin{array}{l}\text { Production Process } \\
\text { Energy (MJ) }\end{array}$} & $\begin{array}{l}\text { Conservation } \\
\text { Energy (MJ) }\end{array}$ & $\begin{array}{l}\text { Approach I } \\
\text { Percentage }\end{array}$ & \multicolumn{2}{l}{$\begin{array}{l}\text { Conservation Approach II } \\
\text { Energy(MJ) }\end{array}$} \\
& Percentage \\
\hline Preliminary Operations & $0.17 \pm 0.01^{a}$ & 0.04 & $0.17 \pm 0.01^{a}$ & 0.24 & $0.17 \pm 0.06^{a}$ & 0.29 \\
First Boiling & $378.00 \pm 6.93^{a}$ & 84.87 & $\mathrm{NA}$ & & $\mathrm{NA}$ & \\
Soaking & $0.08 \pm 0.01^{a}$ & 0.02 & $0.08 \pm 0.01^{a}$ & 0.10 & $0.08 \pm 0.01^{a}$ & 0.14 \\
Dehulling & $2.67 \pm 0.54^{a}$ & 0.60 & $1.68 \pm 0.52^{b}$ & 2.33 & $1.68 \pm 0.52^{b}$ & 2.93 \\
Washing & $\mathrm{NA}$ & & $0.75 \pm 0.03^{a}$ & 1.04 & $0.75 \pm 0.03^{a}$ & 1.31 \\
Second Boiling & $63.00 \pm 4.04^{a}$ & 14.15 & $33.22 \pm 1.73^{b}$ & 46.08 & $18.36 \pm 1.47^{c}$ & 32.08 \\
Wrapping & $1.02 \pm 0.02^{a}$ & 0.23 & $1.02 \pm 0.02^{a}$ & 1.42 & $0.99 \pm 0.19^{a}$ & 1.73 \\
Fermentation & $0.39 \pm 0.30^{a}$ & 0.02 & $0.39 \pm 0.30^{a}$ & 0.12 & $0.09 \pm 0.01^{a}$ & 0.16 \\
Drying & $\mathrm{NA}$ & & $33.90 \pm 1.87^{a}$ & 47.03 & $33.90 \pm 1.87^{a}$ & 59.23 \\
Milling & $\mathrm{NA}$ & & $0.62 \pm 0.05^{a}$ & 0.86 & $0.66 \pm 0.14^{a}$ & 1.15 \\
Packaging & $0.38 \pm 0.09^{a}$ & 0.08 & $0.56 \pm 0.13^{a}$ & 0.78 & $0.56 \pm 0.13^{a}$ & 0.98 \\
Total & $445.40 \pm 17.32^{a}$ & & $72.08 \pm 1.73^{b}$ & & $57.24 \pm 1.73^{b}$ & \\
\hline
\end{tabular}

*NA $=$ Not Applicable; Means followed by different letters across the rows are significantly different $(\mathrm{P}=0.05)$ from one another

Washing was introduced during conservation approaches as a result of need to separate the hulls from the cotyledons although the operation was carried out simultaneously during manual dehulling in traditional process. Soaking, wrapping and fermentation operation of the three processes indicated that there were no significant differences between operations $(\mathrm{P}=0.05)$. This is as a result that the mode of operations was the same in spite of level of processing.

Drying and milling operations consumed $33.90 \pm 1.79 \mathrm{MJ}$ and $0.62 \pm 0.05 \mathrm{MJ}$ corresponding to $47.03 \%$ and $0.86 \%$ respectively in conservation approach I and $33.90 \pm 1.79 \mathrm{MJ}$ and $0.66 \pm 0.14 \mathrm{MJ}$ corresponding to $59.23 \%$ and $1.15 \%$ respectively in conservation approach II as these operations were not applicable to production process. There were no significant differences between the conservation approaches for drying and milling at $(\mathrm{P}=0.05)$. Energy required for packaging in conservation approaches I and II were 1.12MJ and 0.38MJ for Energy required for packaging in conservation approaches I and II were $1.12 \mathrm{MJ}$ and $0.38 \mathrm{MJ}$ for traditional method. There was no significant difference in energy utilization during packaging at $(\mathrm{P}=0.05)$. This can be traced to insignificant electrical energy input that was utilized for packaging in the conservation approaches I and II. There was no significant difference in energy utilization during packaging at $(\mathrm{P}=0.05)$. This can be traced to insignificant electrical energy input that was utilized for packaging in the conservation approaches I and II.

\section{Conclusions}

Energy requirements for processing of soybean into condiments revealed that traditional processing of $1 \mathrm{~kg}$ of soybean into condiment utilized a total of $445.40 \mathrm{MJ}$ where manual and thermal energy were the only forms of energy used, which amounted to $6 \%$ and $94 \%$ of the total energy input. In conservation approach I, energy was reduced to $72.08 \mathrm{MJ}$ with thermal, manual and electrical energy utilizing $87.38 \%, 10.19 \%$ and $2.43 \%$ respectively. The energy was further conserved during conservation approach II to $57.24 \mathrm{MJ}$ comprising of $12.80 \%$ manual, $84.10 \%$ thermal and $3.10 \%$ electrical energy. Conservation approach II permits energy conservation to be $87 \%$ as compared with traditional method in soybean processing into condiment. Also, the total energy demand depends on source of energy, unit operation under consideration, level of production, adopted technology and crop physiology. Therefore, conservation approach II should be adopted 
for processing of soybean into condiment since it is efficient and less consumption of energy.

\section{References}

Aderemi, O., Ilori, M., Aderemi, A., \& Akinbami, J. (2009). Assessment of electrical energy use efficiency in nigerian food industry. , 3(8), . African Journal of Food Science, 3(8), 206-216. Retrieved from http : / / citeseerx.ist.psu.edu/viewdoc/download? $\mathrm{doi}=10.1 .1 .822 .7675 \% 5 \mathrm{C} \& \mathrm{rep}=\mathrm{rep} 1 \% 5 \mathrm{C} \&$ type $=$ pdf

Akande, K. E., Doma, U. D., Agu, H. O., \& Adam, H. M. (2010). Major antinutrients found in plant protein sources: their effect on nutrition. Pakistan Journal of Nutrition, 9(8), 827-832. Retrieved from http: / / scialert . net / archivedetails . php ? issn = $1680-5194 \% 5$ C\&issueno $=63$

Akinoso, R. \& Adedayo, O. A. (2012). Estimating energy requirement in the processing of african locust beans (Parkia biglobosa) into condiment. Indian Society of Agricultural Engineers, 36(3). Retrieved from http://www.indianjournals.com/ijor.aspx? target $=$ ijor : aet $\% 5 \mathrm{C} \&$ volume $=36 \% 5 \mathrm{C} \&$ issue $=3 \% 5$ C\&article $=001$

Akinoso, R., Olapade, A. A., \& Akande, A. A. (2013). Estimation of energy requirement in cowpea flour production in nigeria. $F_{O}$ cusing on Modern Food Industry, 2(2). Retrieved from https://archive.org/stream/ FMFI10008/FMFI10008_djvu.txt

Akinoso, R. \& Omolola, A. O. (2011). Estimating energy requirements in cottage palm oil mill. LAUTECH, Journal of Engineering and Technology, 7(1), 111-115.

Anjorin, I. B., Sanusi, M. S., \& Hussein, J. B. (2015). Energy investigation and conservation of condiment produced from bambara nut (vigna subterranean). International Journal of Advanced Research in Engineering \&5 Management, 1(3), 1-6. Retrieved from https: / / www . researchgate . net / publication / 315249161_Energy_Investigation_and_ Conservation_of_Condiment_Produced_ From_Bambara_Nut_Vigna_Subterranean
Goyal, S. K., Jogdand, S. V., \& Agrawal, A. K. (2014). Energy use pattern in rice milling industries-a critical appraisal. Journal of Food Science and Technologymysore, 51(11), 2907-2916. doi:10.1007/ s13197-012-0747-3

Ibrahim, J., Alex, O., \& Ierve, I. A. (2013). Energy analysis for production of local alcohol (burukutu) in benue state, nigeria. American Journal of Engineering Research, 2(8), 44-50.

Jekayinfa, S. O. \& Bamgboye, A. I. (2006). Estimating energy requirement in cashew (anacardium occidentale l.) nut processing operations. Energy, 31(8-9), 1305-1320. doi:10.1016/j.energy.2005.07.001

Jekayinfa, S. O. \& Bamgboye, A. I. (2007, March). Development of equations for estimating energy requirements in palm-kernel oil processing operations. Journal of Food Engineering, 79(1), 322-329. doi:10.1016/ j.jfoodeng.2006.01.060

Lajolo, F. M. \& Genovese, M. I. (2002). Nutritional significance of lectins and enzyme inhibitors from legumes. Journal of Agricultural and Food Chemistry, 50(22), 6592-6598. 219th National Meeting of the American-Chemical-Society, SAN FRANCISCO, CALIFORNIA, MAR 26-30, 2000. doi:10.1021/jf020191k

Liu, K. (1997). Chemistry and nutritional value of soybean components. In Soybeans: chemistry, technology, and utilization (pp. 25113). Boston, MA: Springer US. doi:10 . 1007/978-1-4615-1763-4_2

Mahlia, T. M. I., Abdulmuin, M. Z., Alamsyah, T. M. I., \& Mukhlishien, D. (2001). An alternative energy source from palm wastes industry for malaysia and indonesia. Energy Conversion and Management, 42(18), 2109-2118. doi:10 . 1016 / S0196 - 8904(00 ) 00166-7

Mrini, M., Senhaji, F., \& Pimentel, D. (2002). Energy analysis of sugar beet production under traditional and intensive farming system and impart on sustainable agriculture in morocco. Journal of Sustainable Agriculture, 20, 5-28. doi:10.1300/ J064v20n04_03 
Energy usage during production of soybean condiment 119

Oboh, G. (2006). Nutrient and antinutrient composition of condiments produced from some fermented underutilized legumes. Journal of Food Biochemistry, 30(5), 579-588. doi:10.1111/j.1745-4514.2006.00083.x

Rajput, R. K. (2001). Thermal engineering. New Delhi. Laxmi Publications (P) Ltd.

Wang, L. (2009). Energy efficiency and management in food processing facilities. CRC, Taylor and Frances Group Boca Raton. Retrieved from https:// www. crcpress . com/Energy-Efficiency-and-Managementin - Food- Processing - Facilities / Wang / p / book/9781420063387 